\title{
The effect of storage temperature, time and spore source on the germination of Cronartium flaccidum and Peridermium pini aeciospores in vitro
}

\author{
JUHA KAITERA
}

\begin{abstract}
KAITERA, J. 1999: The effect of storage temperature, time and spore source on the germination of Cronartium flaccidum and Peridermium pini aeciospores in vitro. Karstenia 39: 69-75. Helsinki. ISSN 0435-3402

The effect of temperature and time of storage on the germination of aeciospores of Cronartium flaccidum (one source) and Peridermium pini (5 sources) were studied on malt agar with added pine needle extracts, and water agar. The storage temperatures ranged from $-160{ }^{\circ} \mathrm{C}$ to $+25^{\circ} \mathrm{C}$, and the time of storage from 7 days to 2 years. The rate of aeciospore germination remained higher after storage at low temperatures than at high temperatures, as spores stored at high temperatures lost their viability within a few months after storage. The two-year period of storage, however, reduced the germinability of the aeciospores significantly even at low temperatures. Aeciospores of $C$. flaccidum lost their viability more rapidly than those of $P$. pini.
\end{abstract}

Storage strongly reduced the subsequent ability of germ tubes to form vesicles. No vesicles were formed on a water agar substrate after $3-6$ month-storage at $+4-+25^{\circ} \mathrm{C}$. At lower temperatures, the ability to form vesicles decreased more slowly, but vesicles were formed in individual spore samples as abundantly as at the beginning of the experiment when these were stored at between $-22{ }^{\circ} \mathrm{C}$ or $-70{ }^{\circ} \mathrm{C}$ for 2 years. The results suggest that aeciospores should be stored at low temperatures when needed for future inoculations in order to retain the highest possible viability.

Key words: Cronartium flaccidum, germination, Peridermium pini, pine stem rust, Pinus sylvestris, storage, temperature

Juha Kaitera. The Finnish Forest Research Institute, Rovaniemi Research Station, P.O. Box 16, FIN-96301 Rovaniemi, Finland

\section{Introduction}

The pine stem rusts Peridermium pini (Pers.) Lév. and Cronartium flaccidum (Alb. \& Schwein.) G. Winter are among the most destructive pathogens damaging Scots pine (Pinus sylvestris L.) in Scandinavia (Jorstad 1928, Rennerfelt 1943). In Finland, P. pini is the dominating species, but $C$. flaccidum occurs also sporadically across the country (Liro 1908, Hantula et al. 1998, Kaitera \& Hantula 1998, Kaitera et al. 1999).

Cronartium spp. and Peridermium spp. are also among those rusts that have been successfully cultured on specific media (e.g. Harvey \& Grasham 1974, Allen et al. 1988, Pei \& Pawsey 1990, Moricca \& Ragazzi 1994). Peridermium pini aeciospores germinate at temperatures be- tween $5{ }^{\circ} \mathrm{C}$ and $30^{\circ} \mathrm{C}$, the optimum being $20-25^{\circ} \mathrm{C}$ (Klingström 1963, Olembo 1971a). The frequency of germ tubes differentiating to form vesicles (Klingström 1963, Gibbs et al. 1988), however, varies greatly with different incubation temperatures (Olembo 1971a). Germination is reduced when spores are seeded at high densities with pH between 2.0-7.5 (Olembo 1971a). The optimum $\mathrm{pH}$ for maximum germination is 5.5 (Olembo 1971a). In addition, the prevailing relative humidity of the air must be over $80 \%$ to promote germination (Olembo 1971a). According to Klingström (1963) P. pini aeciospores maintain their viability unaltered for at least one year after of being stored dry at $0{ }^{\circ} \mathrm{C}$. 
The aim of this study was to investigate the effect of storage temperature and storage time on the germination of pine stem rust aeciospores from different sources on two agar media in vitro. The information thus obtainable is important, as aeciospores must, in most cases, be stored for some time before final usage, e.g. in inoculations, and therefore, the viability of the spores needs to be maintained high for as long as possible after spore collection.

\section{Material and methods}

Rust aeciospores were collected from unruptured aecia from a number of lesions (a mixed sample from several lesions per location) during dry weather in late June 1995. The aeciospores represented four geographic $P$. pini populations (Jokela 1, Kesälahti 2, Inari, Pudasjärvi) and one C. flaccidum population (Kolari 1) in Finland (for identification of the rust populations, see Hantula et al. 1998 and Kaitera et al. 1999). Shortly after collection, the aeciospores were air-dried and sieved through a fine mesh onto petri dishes just before storage. Initial viability was measured by dusting spores onto water agar followed by incubation for $24 \mathrm{~h}$ at $25^{\circ} \mathrm{C}$. The germination rates of the spore sources (Jokela, Kesälahti, Inari, Pudasjärvi and Kolari) were $95 \%, 80 \%$, $100 \% 98 \%$ and $96 \%$ on water agar at the beginning of the experiment. Aeciospores were stored dry in Eppendorf vials in the dark at $25^{\circ} \mathrm{C}$ on a laboratory worktop, at $15^{\circ} \mathrm{C}$ in a warming cupboard, at $4^{\circ} \mathrm{C}$ in a cold room, at $-7^{\circ} \mathrm{C}$ in a refrigerator, at $-22^{\circ} \mathrm{C}$ in a cold room, at -70 ${ }^{\circ} \mathrm{C}$ in a freezer or at $-160{ }^{\circ} \mathrm{C}$ in a tank containing liquid nitrogen. Spores from a vial of each aeciospore source were dusted on both water agar or $1.5 \%$ malt agar with added pine needle extract (Kurkela 1979) after storage for 7 days, 1 month ( 35 days), 3 months, 6 months, 1 year and 2 years. The frequency of germ tube formation and their subsequent ability to form vesicles (Klingström 1963, Gibbs et al. 1988) was estimated for each sample (vial) using the following classes: Abundant vesicles ( $>50 \%$ of the germinated spores bearing vesicles), moderate number of vesicles $(10-50 \%)$, low number of vesicles $(1-9 \%)$ and no vesicles $(0 \%)$. Aeciospore germination was determined from ten randomly sampled microscope fields under a light microscope after a $24 \mathrm{~h}$ incubation period at $25{ }^{\circ} \mathrm{C}$ on the agar plates. Before statistical analysis, the percent figures were arcsinetransformed. The germination of the spores was compared between spore sources, storage temperatures, storage times, and media by analysis of variance using the GLM procedure of SAS (Anonymous 1989). The germination rates of individual spore sources were compared using Tukey's test (Anonymous 1989).

\section{Results}

Analysis of variance revealed that storage time was the most significant explaining variable, when modelling the variation in germination on both media (Table 1). Also temperature, spore source, and their interactions, were statistically significant in modelling the germination of the aeciospores, regardless of the basal media (Table 1). These variables and their interactions explained $80 \%$ of the total variation in spore germination. When modelling the variation in germination separately on the different media, the former variables and their interactions were statistically significant at $0.001 \mathrm{p}$-level (ANOVA, data not shown), The respective models explained $86 \%$ and $77 \%$ of the total variation on water agar and on malt agar with added pine needle extract.

Table 1. ANOVA table of the effect of storage time (A), storage temperature (inoculum C), media (D), and their first-degree interactions on the germination of Peridermium pini and Cronartium flaccidum aeciospores after a $24 \mathrm{~h}$ incubation period.

\begin{tabular}{lrrl}
\hline Source & df & \multicolumn{1}{c}{$F$} & $P>F$ \\
\hline Time (A) & 6 & 1076.89 & 0.0001 \\
Temperature (B) & 6 & 464.67 & 0.0001 \\
Inoculum (C) & 4 & 204.83 & 0.0001 \\
Media (D) & 1 & 614.37 & 0.0001 \\
A X B & 30 & 52.14 & 0.0001 \\
A X C & 24 & 21.35 & 0.0001 \\
A X D & 5 & 266.69 & 0.0001 \\
B X C & 24 & 20.29 & 0.0001 \\
B X D & 6 & 4.85 & 0.0001 \\
CX D & 4 & 48.25 & 0.0001 \\
\hline
\end{tabular}

After 7-day storage at temperatures below $4{ }^{\circ} \mathrm{C}$, the germination of the aeciospores remained almost unaffected on water agar, regardless of the spore source. At higher temperatures spore samples from different sources showed statistically significant differences in germination (e.g. Pudasjärvi > Kesälahti; Tukey's test, data not shown). Thereafter, the germination of aeciospores from individual aeciospore sources fell rapidly at $25^{\circ} \mathrm{C}$ to nearly zero after 3 months (Fig. 1). No statistically significant differences occurred among the spore sources after 6 months at $15^{\circ} \mathrm{C}$ and $25^{\circ} \mathrm{C}$ on water agar. At lower temperatures, the germination rate of the aeciospores diminished slowly with increasing time of storage (Fig. 1). After storage of 2 years, germination of the aeciospores was less than $20 \%$ in nearly all the cases. The aeciospores maintained their viability best when stored at $-22^{\circ} \mathrm{C}$. Storage at $-160^{\circ} \mathrm{C}$ broke some of the vials during the experiment, leading to the rejection of some of the 
observations due to possible condensation of moisture in the test tubes. Nevertheless, the possibility that extremely low temperatures (below $-70^{\circ} \mathrm{C}$ ) may also have some additional inhibiting (or for some P. pini sources even stimulating) effects on the germination of the aeciospores when compared to higher temperatures below $0^{\circ} \mathrm{C}$ cannot be excluded. There were statistically significant differences between individual spore sources at different temperatures after for different storage times, but in general C. flaccidum aeciospores (Kolari) lost their viability more rapidly than those of $P$. pini (e.g. Pudasjärvi). On malt agar with pine needle extract, the aeciospores germinated less vigorously than on water agar, regardless of the spore source. On the former medium, germination was more variable giving rise to statistically significant differences among aeciospore sources at different temperatures (Tukey's test, data not shown). Nevertheless, $C$. flaccidum germinated poorest among spore sources also on this medium, as was the case on water agar, regardless of the storage time or temperature. Also a general downward trend in germination on water agar was evident after the 1month storage period, but some additional stimulative effect was observed when compared to germination after the 7-day storage period for all $P$. pini sources at some temperatures.

Vesicles were produced variably by germ tubes originating from individual spore sources during the experiment. Peridermium pini spores from Inari and Pudasjärvi produced vesicles most frequently on water agar, whereas $C$. flaccidum spores from Kolari produced only a few individual vesicles during the experiment (Table 2). On water agar, the frequency of vesicles remained unaffected by a 7-day storage period at all temperatures. Thereafter, the frequency of vesicle production by $P$. pini after storage for $1-$ 6 months at $4-25^{\circ} \mathrm{C}$ diminished (Table 2). Storage time and temperature did not significantly affect the frequency of $C$. flaccidum vesicles. Vesicles occurred frequently after storage below $-7{ }^{\circ} \mathrm{C}$, depending somewhat on the aeciospore source. In most cases, the frequency of vesicle production remained high after storage for 1 year. The formation of vesicles was highest in material stored at the lowest temperatures, although the breaking of some of the vials at $-160^{\circ} \mathrm{C}$ prevented final conclusions to be drawn. Vesicles were formed most frequently on water agar by ae-
Table 2. Frequency of Peridermium pini $\left({ }^{1}\right)$ and Cronartium flaccidum $\left({ }^{2}\right)$ aeciospores producing germ tubes with vesicles after storage periods of 7 days to 2 years at temperatures between $25^{\circ} \mathrm{C}$ and $-160^{\circ} \mathrm{C}$, followed by inoculation on water agar and incubation for $24 \mathrm{~h} .1=$ No vesicles, $2=$ Low number of vesicles $(1-9 \%$ of the germinated spores producing vesicles), $3=$ Moderate number of vesicles $(10-50 \%), 4=$ Abundant vesicles $(>50 \%),-=$ Missing data.

\begin{tabular}{|c|c|c|c|c|c|c|c|}
\hline & & & & Storage & time & & \\
\hline $\begin{array}{l}\text { Spore } \\
\text { source }\end{array}$ & \% & $7 d$ & $\begin{array}{c}1 \\
\text { month }\end{array}$ & $\begin{array}{c}3 \\
\text { months }\end{array}$ & $\begin{array}{c}6 \\
\text { months }\end{array}$ & $1 \mathrm{yr}$ & $2 \mathrm{yrs}$ \\
\hline Inari $^{1}$ & $\begin{array}{r}25 \\
15 \\
4 \\
-7 \\
-22 \\
-70 \\
-160\end{array}$ & $\begin{array}{l}4 \\
4 \\
4 \\
4 \\
4 \\
4 \\
4\end{array}$ & $\begin{array}{l}3 \\
4 \\
3 \\
4 \\
4 \\
4 \\
4\end{array}$ & $\begin{array}{l}1 \\
3 \\
4 \\
4 \\
4 \\
4 \\
4\end{array}$ & $\begin{array}{l}1 \\
1 \\
1 \\
3 \\
4 \\
4 \\
4\end{array}$ & $\begin{array}{l}1 \\
1 \\
1 \\
3 \\
4 \\
4 \\
1\end{array}$ & $\begin{array}{l}1 \\
1 \\
1 \\
3 \\
4 \\
4 \\
-\end{array}$ \\
\hline Pudasjärvi & $\begin{array}{r}i^{1} \quad 25 \\
15 \\
4 \\
-7 \\
-22 \\
-70 \\
-160\end{array}$ & $\begin{array}{l}3 \\
4 \\
4 \\
3 \\
3 \\
4 \\
3\end{array}$ & $\begin{array}{l}3 \\
4 \\
3 \\
4 \\
4 \\
3 \\
3\end{array}$ & $\begin{array}{l}1 \\
3 \\
3 \\
3 \\
3 \\
3 \\
3\end{array}$ & $\begin{array}{l}1 \\
1 \\
2 \\
3 \\
3 \\
3 \\
4\end{array}$ & $\begin{array}{l}1 \\
1 \\
1 \\
3 \\
2 \\
2 \\
1\end{array}$ & $\begin{array}{l}1 \\
1 \\
1 \\
3 \\
2 \\
1 \\
3\end{array}$ \\
\hline Kesälahti ${ }^{1}$ & $\begin{array}{r}25 \\
15 \\
4 \\
-7 \\
-22 \\
-70 \\
-160\end{array}$ & $\begin{array}{l}3 \\
1 \\
3 \\
3 \\
3 \\
3 \\
1\end{array}$ & $\begin{array}{l}3 \\
3 \\
3 \\
3 \\
3 \\
3 \\
3\end{array}$ & $\begin{array}{l}1 \\
4 \\
1 \\
1 \\
3 \\
4 \\
3\end{array}$ & $\begin{array}{l}1 \\
1 \\
1 \\
1 \\
1 \\
4 \\
3\end{array}$ & $\begin{array}{l}1 \\
1 \\
1 \\
2 \\
3 \\
3 \\
1\end{array}$ & $\begin{array}{l}1 \\
1 \\
1 \\
1 \\
2 \\
2 \\
-\end{array}$ \\
\hline Jokela $^{1}$ & $\begin{array}{r}25 \\
15 \\
4 \\
-7 \\
-22 \\
-70 \\
-160\end{array}$ & $\begin{array}{l}1 \\
3 \\
3 \\
3 \\
4 \\
3 \\
1\end{array}$ & $\begin{array}{l}1 \\
1 \\
3 \\
3 \\
3 \\
3 \\
3\end{array}$ & $\begin{array}{l}1 \\
1 \\
1 \\
1 \\
3 \\
3 \\
3\end{array}$ & $\begin{array}{l}1 \\
1 \\
2 \\
3 \\
3 \\
3 \\
2\end{array}$ & $\begin{array}{l}1 \\
1 \\
1 \\
1 \\
3 \\
3 \\
-\end{array}$ & $\begin{array}{l}1 \\
1 \\
1 \\
1 \\
1 \\
2 \\
-\end{array}$ \\
\hline Kolari $^{2}$ & $\begin{array}{r}25 \\
15 \\
4 \\
-7 \\
-22 \\
-70 \\
-160\end{array}$ & $\begin{array}{l}1 \\
1 \\
2 \\
1 \\
1 \\
1 \\
1\end{array}$ & $\begin{array}{l}1 \\
1 \\
1 \\
1 \\
1 \\
1 \\
1\end{array}$ & $\begin{array}{l}1 \\
1 \\
1 \\
1 \\
2 \\
1 \\
1\end{array}$ & $\begin{array}{l}1 \\
1 \\
1 \\
1 \\
1 \\
2 \\
2\end{array}$ & $\begin{array}{l}1 \\
1 \\
1 \\
1 \\
1 \\
1 \\
1\end{array}$ & $\begin{array}{l}1 \\
1 \\
1 \\
1 \\
1 \\
1 \\
-\end{array}$ \\
\hline
\end{tabular}

ciospores stored at $-22^{\circ} \mathrm{C}$ to $-70{ }^{\circ} \mathrm{C}$ in the case of $P$. pini from Inari during the entire 2-year storage period. On malt agar with pine needle extract, vesicles were formed only occasionally in $P$. pini from Inari, Pudasjärvi and Jokela (one case). No trends in their frequency were observed in relation to either storage temperature or time. 

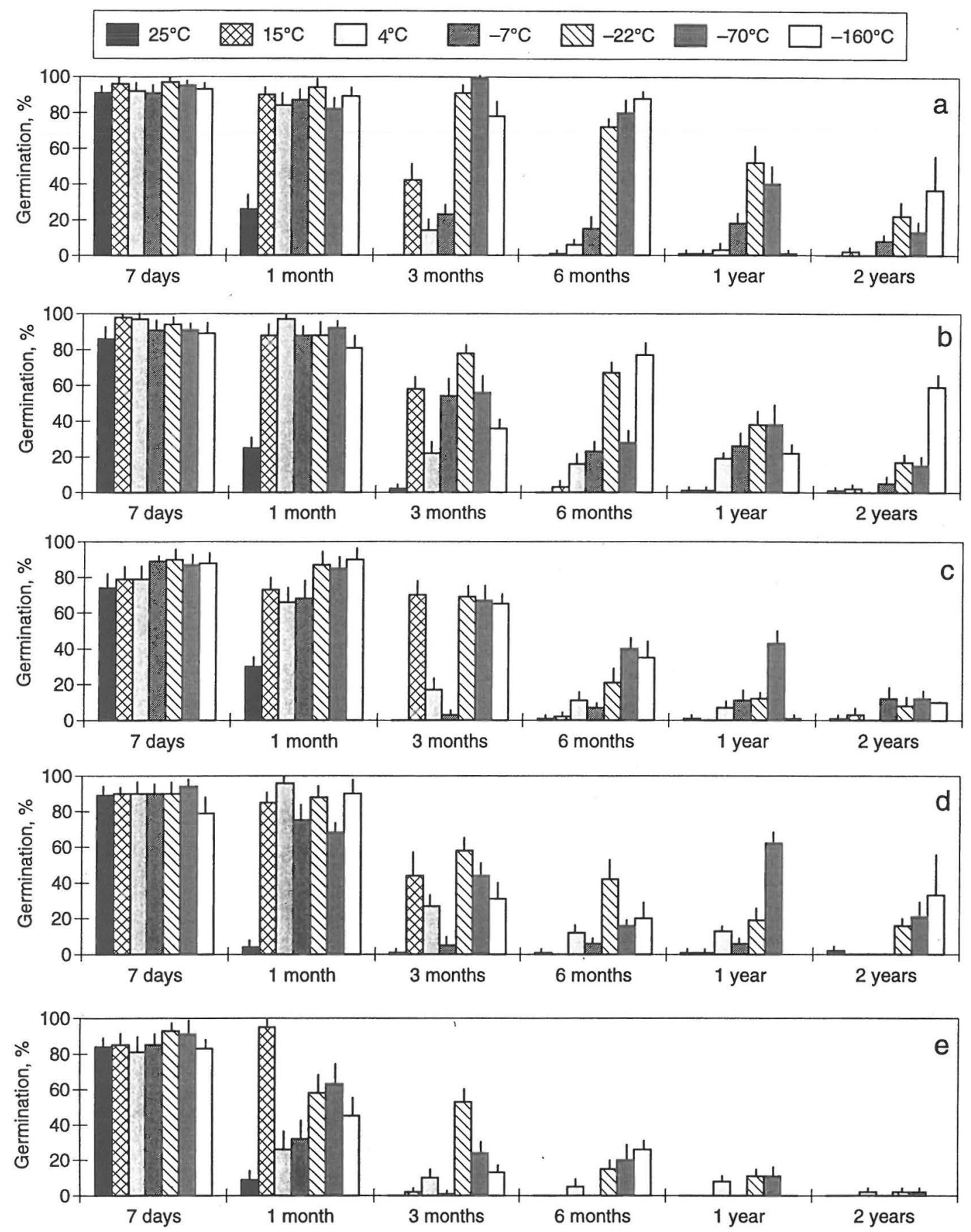

Fig. 1. Germination (\%) of Peridermium pini aeciospores from Inari (a, f), Pudasjärvi (b, g), Kesälahti (c, h) and Jokela (d, i), and of Cronartium flaccidum aeciospores from Kolari $(\mathrm{e}, \mathrm{j})$ after storage at $25^{\circ} \mathrm{C}, 15^{\circ} \mathrm{C}, 4^{\circ} \mathrm{C},-7^{\circ} \mathrm{C}$, 

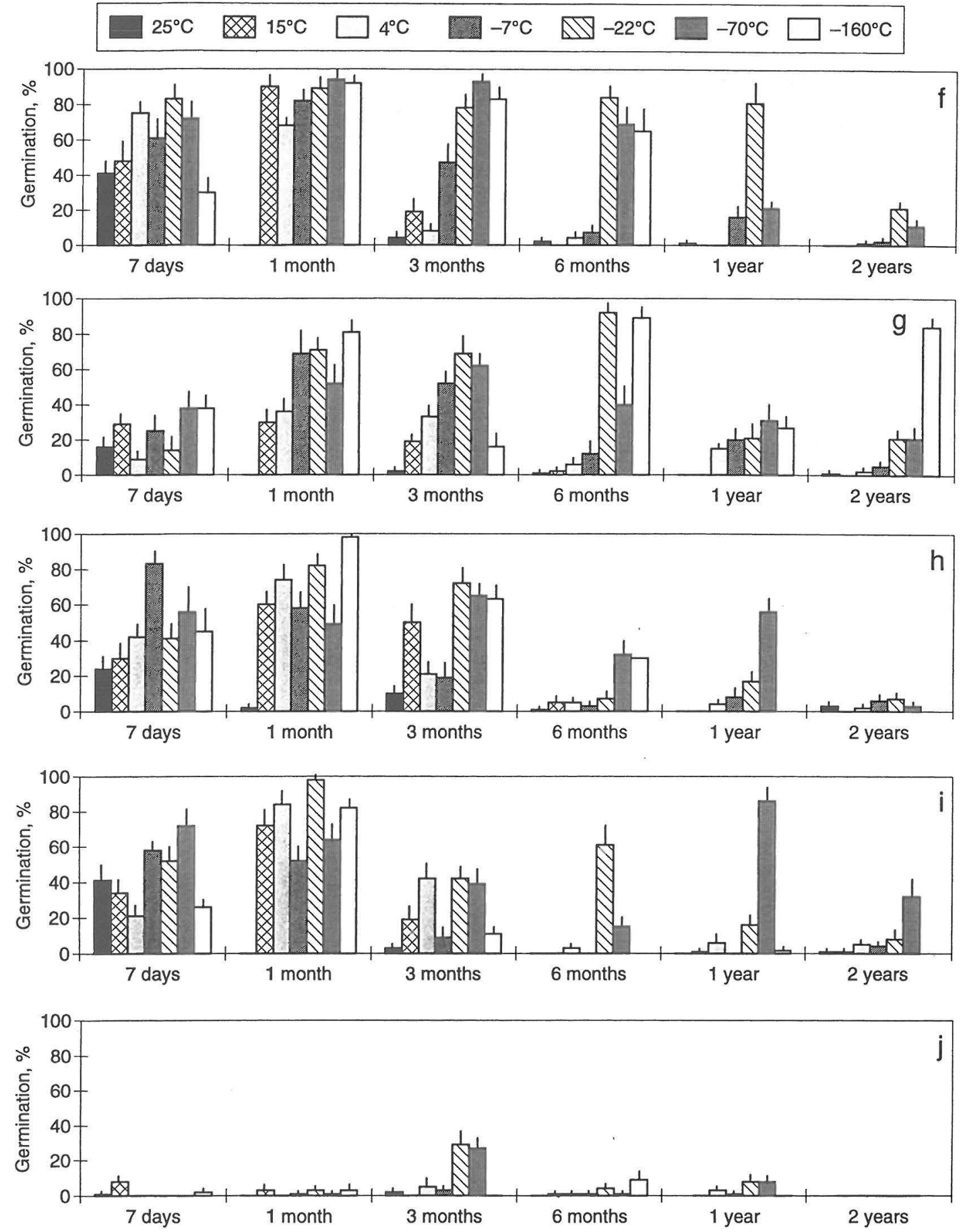

$-22^{\circ} \mathrm{C},-70^{\circ} \mathrm{C}$ and $-160^{\circ} \mathrm{C}$ for 7 days, 1 month, 3 months, 6 months, 1 year and 2 years, followed by $24 \mathrm{~h}$ incubation on water agar (a-e) and malt agar added with pine needle extract $(f-j)$. Vertical bars indicate the SD of the mean. 


\section{Discussion}

The results of the present study revealed that the germination of aeciospores was rapidly reduced when stored at high temperatures, whereas high viability was maintained for longer at temperatures below $0{ }^{\circ} \mathrm{C}$. Earlier Klingström (1963) had shown that 10 days at $-27^{\circ} \mathrm{C}$ did not affect the capacity of $P$. pini aeciospores to germinate. Also, aeciospores stored at $-25^{\circ} \mathrm{C}$ for 1 year were still infective on pine (Klingström 1972). At higher temperatures, Siggers (1947) reported that only a few aeciospores of fusiform rust (C. quercuum (Berk.) Miyabe ex Shirai f. sp. fusiforme) preserved their viability after a 7 -month -storage period at below $10^{\circ} \mathrm{C}$. Klingström (1963), however, noted that germination of $P$. pini aeciospores remained unaffected at $4{ }^{\circ} \mathrm{C}$ for at least a year. In this study, the germination of $P$. pini aeciospores was greatly reduced after long-term storage at temperatures above $0{ }^{\circ} \mathrm{C}$, the reduction being most rapid at the highest temperatures applied. Also, Lightle (1955) reported that germination of Endocronartium harknessii (Moore) Hiratsuka (syn. P. harknessii Moore) aeciospores was less than $15 \%$ after a 14-month -incubation period at $4{ }^{\circ} \mathrm{C}$. In addition, according to Klingström (1972), the germination of $P$. pini aeciospores declined after a 4-week-storage period at $20^{\circ} \mathrm{C}$, which is in rather good agreement with the results of the present study (at $25^{\circ} \mathrm{C}$ after a similar time of storage).

In this study, the unexplained variation in the model describing aeciospore germination was low suggesting that the effect of storage moisture on spore viability was minimal. In some cases, however, condensed moisture in the test tubes at $-160^{\circ} \mathrm{C}$, due to breaking of some of the tubes during storage may have affected the germinability of the spores contained within them. Earlier, Klingström (1963) reported that condensation in test tubes and collecting of $P$. pini spores in rainy weather decreased aeciospore germination. Lightle (1955), however, found only small variation in viability between air-dried, desiccated and undried aeciospores of $P$. harknessii after a 20 -month-incubation period at $4{ }^{\circ} \mathrm{C}$.

In the present study, viability of $C$. flaccidum aeciospores decreased more steeply than that of $P$. pini aeciospores especially at low temperatures. No similar reports are, however, available to confirm the applicability of the results. In addi- tion, C. flaccidum was found to produce vesicles less frequently than $P$. pini regardless of the storage temperature, time or medium used. According to Gibbs et al. (1988) and Kaitera et al. (1999), there is high variation in vesicle formation between $P$. pini and C. flaccidum, with $P$. pini producing vesicles more frequently than $C$. flacci$d u m$. In the present study, the formation of vesicles was greatly reduced when storage was arranged at high temperatures, but their formation remained relatively unaltered after storage at lower temperatures. No similar studies are available to confirm these results.

In this study, germination was poorer and more variable on malt agar with pine needle extract than on water agar, regardless of the time or temperature of storage, or the spore source. The general trend on the effect of storage time and temperature in germination was, however, similar to that on water agar. Earlier, Klingström (1963) reported that $P$. pini aeciospores germinated better on agar media with added nutrients than on water agar. Similarly, aeciospores of $C$. ribicola (J. C. Fisch.) Rabenh. germinated better on Ribesleaf-decoction agar than on water agar (Van Arsdel et al. 1956). Olembo (1971b), however, reported that added pine needle extract had a more pronounced inhibiting effect on $P$. pini aeciospore germination as compared to pure water agar. This was also the observation made in the present study.

Acknowledgements: I wish to thank Ms Leena Seitamäki for her assistance in the laboratory, Tarmo Aalto, B.Sc. (For.), for drawing the figures for the publication, and Erkki Pekkinen, MSc. (For.), for checking the English.

\section{References}

Allen, E. A., Blenis, P. V. \& Hiratsuka, Y. 1988: Axenic cultures of Endocronartium harknessii. - Mycologia 80: $120-123$.

Anonymous 1989: SAS/STAT user's guide, Version 6, Fourth Edition, Volume 2, Cary, NC: SAS Institute Inc.

Gibbs, J. N., England, N. \& Wolstenholme, R. 1988: Variation in the pine stem rust fungus Peridermium pini in the United Kingdom. - Plant Path. 37: 45-53.

Harvey, A. E. \& Grasham, J. L. 1974: Axenic culture of the mononucleate stage of Cronartium ribicola. Phytopathology 64: 1028-1033.

Jørstad, I. 1928: Nord-Norges skogsykdommer. Tidsskr. Skogbr. 36: 365-456. 
Hantula, J., Niemi, M., Kaitera, J., Jalkanen, R. \& Kurkela, T. 1998: Genetic variation of pine stem rust in Finland as determined by Random Amplified Microsatellites (RAMS). - Eur. J. For. Path. 28: 361-372.

Kaitera, J. \& Hantula, J. 1998: Melampyrum sylvaticum, a new alternate host for pine stem rust Cronartium flaccidum. - Mycologia 90: 1028-1030.

Kaitera, J., Seitamäki, L., Hantula, J., Jalkanen, R. \& Kurkela, T. 1999: Inoculation of known and potential alternate hosts with Peridermium pini and Cronartium flaccidum aeciospores. - Mycol. Res. 103: $235-241$.

Klingström, A. 1963: Germination of aeciospores of Peridermium pini (Pers.) Lév. - Svensk Bot. Tidskr. 57: $277-282$.

Klingström, A. 1972: Melampsora pinitorqua (Braun) Rostr. and Peridermium pini (Willd.) Kleb., inoculation problems and techniques. - In: Biology of rust resistance in forest trees. Proc. NATO-IUFRO adv. Study Instit. U.S. Dept. Agric. For. Serv. Miscellaneous Publ. 1221: 313-323.

Kurkela, T. 1979: Lophodermium seditiosum Minter et al. -sienen esiintyminen männynkaristeen yhteydessä. - Folia For. 393: 1-11.

Lightle, P. C. 1955: Longevity of Peridermium harknessii aeciospores stored at $40^{\circ} \mathrm{F}$. - Pl. Dis. Rep. 39: 983-984.
Liro, J. I. 1908: Uredinae Fennicae. - Bidr. Finlands natur och folk 65: 1-567.

Moricca, S. \& Ragazzi, A. 1994: Axenic culture of the aecial state of Cronartium flaccidum from Italy. Mycol. Res. 98: 1258-1262.

Olembo, T. W. 1971a: A study on the mode of infection of Pinus sylvestris L. by Peridermium pini (Pers.) Lév. - Forestry 44: 67-79.

Olembo, T. W. 1971b: A study of some factors of resistance of Pinus sylvestris L. to Peridermium pini (Pers.) Lév. - Forestry 44: 81-86.

Pei, M. H. \& Pawsey, R. G. 1990. Axenic culture of Peridermium pini. - Mycol. Res. 95: 108-115.

Rennerfelt, E. 1943: Om vår nuvarande kunskap om törskatesvampen (Peridermium pini) och sättet för dess spridning och tillväxt. - Sv. Skogsvårdsför. Tidskr. 41: 305-324.

Siggers, P. V. 1947: Temperature requirements for germination of spores of Cronartium fusiforme. - Phytopathology 37: 855-864.

Van Arsdel, E. P., Riker, A. J. \& Patton, R. F. 1956: The effects of temperature and moisture on the spread of white pine blister rust. - Phytopathology 46: $307-$ 318.

Received on 3 September 1999 